\title{
Strategies for Sustainable Business Models for Open Educational Resources
}

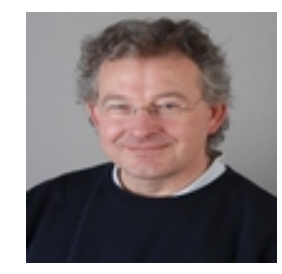

F.H.T de Langen

Open University, The Netherlands

\section{Abstract}

For several years, the importance of continuous education has been stressed by several governmental and non-governmental institutions (Janssen \& Schuwer, 2012; Marshall \& Casserly, 2006). Education is seen as important both for personal growth and empowerment for one's personal wellbeing and for developing the professional capabilities needed in today's society. In his 2011 State of the Union address President Obama put emphasis on the government's ambitions to "out-innovate and out-educate" the rest of the world. Almost at the same time, at the Davos World Economic Forum (2011), the urgency of appropriate education was stressed, observing that the current lack of adequately educated people hinders prosperity and economic growth in the near future. The OECD is preparing a proposal to translate these intentions into a concrete policy.

Keywords : Open education resources; business model 


\section{Introduction}

Kumar (2009) stated that the present organization of education will not be able to meet the increasing demand for education, especially in newly developing countries such as India and China. He saw the answer to this in the increasing possibilities of the Internet in combination with open educational resources, which create an opportunity to broaden the access of education towards different sectors and communities beyond existing possibilities.

Open educational resources are one of the instruments which can contribute to this development. Recently, ideas emerged on how open access and the use of educational resources would serve education around the world. This vision of developing and sharing OER, open educational resources, has great potential to substantially help solve some existing problems by enabling people across continents and organizations to transform their talents into professional competences and growth (see for example, Kumar, 2009; ETA, 2011; Stacey, 2012).

Yet, due to the credit- and euro-crisis, but also as result of a change in (political) orientation, we see a withdrawal of funds away from OER, towards other goals. For example, the House Appropriations Committee adjusted the TAACCCT grant program (Watters, 2011):

None of the funds made available by this Act for the Department of Labor may be used to develop new courses, modules, learning materials, or projects in carrying out education or career job training grant programs unless the Secretary of Labor certifies, after a comprehensive market-based analysis, that such courses, modules, learning materials, or projects are not otherwise available for purchase or licensing in the marketplace or under development for students who require them to participate in such education or career job training grant programs.

Similar statements have been made in the Netherlands (verbal communication; also see the blog of Wiley, 2012). It is therefore important to think about the financial sustainability of open educational resources. This does not mean necessarily that an OER-organization has to generate a competitive return on investment in financial terms for the providers, but it helps to maximize the effect of the supply of OER within the financial boundaries or to expand these boundaries and expand possibilities. Efforts to supply, to exploit, and to maintain OER can be financed through voluntary activities, but will also require financial support of some kind (see the discussion in Stacey, 2012).

In this article, we will discuss briefly what a business model is, after which the motives of participants of the OER-system will be given. Based on work in de Langen (2011) we 
can give an overview of possible business models in terms of the Business Canvas of Osterwalder and Pigneur (2009).

Moving on from the simple Osterwalder Business Canvas towards more complex value networks, we will argue that an OER-business model should involve a network approach, but also a reversal of the concepts of the consumer and the stakeholder as used in regular business analysis.

\section{Open Business Models for OER}

The fact that educational materials should be given away for free inspired many authors to try to develop revenue models to analyze the different sources of possible funding for OER (Downes, 2006; Dholakia et al., 2006; Koohang et al., 2007; OECD, 2007; Guthrie et al., 2008; Lane, 2008; de Langen, 2008; Stacey, 2012). By focusing on revenue models (Afuah, 2004), these contributions ignore the complexity of the business model, which provides an integrated framework from inputs to the customer (Osterwalder, 2004; Chesbrough, 2006, Osterwalder \& Pigneur, 2009, see Figure 1).

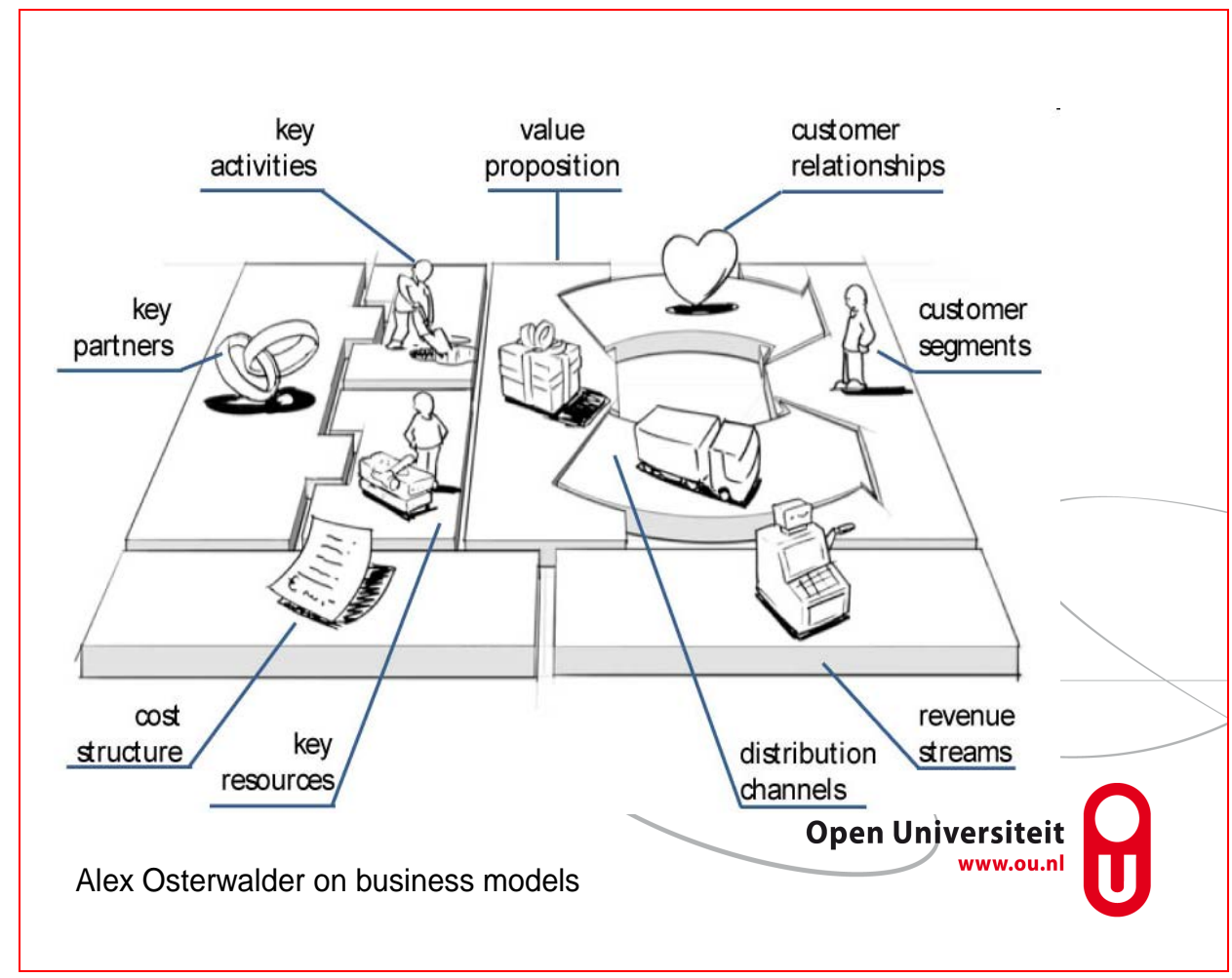

Figure 1. Alex Osterwalder's Business Canvas.

There is a shift in attention in these new (open) business models. Traditionally business models are used to describe the relationship between resources, activities, and the product offering (Porter, 1985; De Wit \& Meyer, 2005), viewed from the organization. 
In modern open business models (especially Osterwalder \& Pigneur, 2009, see for example Business Model Generation, 2011), the preferences of the consumer are central. This is combined with the importance of alliances and cooperation on the side of the suppliers. Those two trends are apparent in the work of Prahalad and Krishan (2008), for whom each consumer is unique $(\mathrm{n}=1)$, and co-creatorship between the supplier and the consumer exists. This uniqueness requires multiple partnerships to fulfill all the preferences of this unique consumer ( $r=g$ in the philosophy of Prahalad and Krishan, 2008). The business model is opened up in two ways, the influence of the customer and the necessity of partnerships, shifting the view from the internal organization towards the environment.

Central to this open approach is the question of why customers and partners are interested in the offerings of the organization. In de Langen (2011) and Bitter and de Langen (2012) the methodology of these business models is linked to the philosophy of open educational resources. The question then becomes why people, institutions, and organizations participate in OER.

To answer this, Hylén's (2009) listing of motives was used to analyze the motives of participants in OER (government, organizations, individuals). Table 1 gives an overview of the arguments used (see de Langen, 2011 for a more extensive treatment). 
Table 1

Motives of Participants in OER

\begin{tabular}{|c|c|}
\hline $\begin{array}{l}\text { Governments } \\
\text { a. Sectoral arguments } \\
\text { b. National arguments }\end{array}$ & $\begin{array}{l}\text { Users } \\
\text { a. Institutionalised user, educators/institutions, } \\
\text { using the open educational resources in their own } \\
\text { teachings } \\
\text { b. Students and self-learners, who want to further } \\
\text { their knowledge }\end{array}$ \\
\hline Organizations & Individuals \\
\hline a. The public good motive & a. Altruistic reasons \\
\hline b. The efficiency motive & b. Non-monetary gain \\
\hline c. The marketing motive & $\begin{array}{l}\text { c. Commercial reasons } \\
\text { d. Arguments of usefulness or costs }\end{array}$ \\
\hline
\end{tabular}

If the different motives of participants or stakeholders in OER confronted each other, it would be possible to distinguish fields of tension where the motives of one stakeholder disagree with those of other stakeholders, for example when individuals supply OER from an altruistic motive, but their materials are used for marketing purposes by the organization offering the materials to potential students. It is also possible that the motives enforce each other. Based on overlapping motives, several different business models can be distinguished.

1. Freemium: Giving away OER to get paying students, for example the MITexperience. This is the marketing motive. Also the split-component model of Mulder (2011) can be seen as a variant of the freemium model.

2. Efficiency: Exchanging OER to become more efficient and effective, for example Wikiwijs (http:// www.wikiwijs.nl/sector/) or several governmentfinanced knowledge bases. Governments and educational organizations are prepared to contribute to the development and exploitation of these kinds of educational instruments because they expect the cost of education to decline and/ or the efficiency to rise. 
3. Subsidizing: Because of the perceived importance of education for economic development and social cohesion, different (international) institutions and national governments will subsidize the development and exploitation of OER. The involved organizations have to show that their OER does have a positive effect on education locally or abroad. Several initiatives were financed by private institutions (such as the William and Flora Hewlett Foundation), public institutions (such as the different European governments under the Lisbon agenda), and international public institutions (such as the European Union and UNESCO).

4. Platforming: Once an organization has a respected supply of OER, other producers of educational resources could choose to link their resources to the portal of this organization, or even host their materials there. The hosting organization can ask for a contribution to the costs, supplying the OER for free. For example, The ARIADNE infrastructure provides access to some hundreds of thousands of learning resources from repositories and collections around the world. This infrastructure is serving a dual purpose: First, it hosts repositories for collaborating institutions that use the ARIADNE tools in order to set up and populate their repositories using the ARIADNE infrastructure; second, it harvests and stores locally metadata records from federated repositories that are hosted elsewhere and operated by institutions cooperating with ARIADNE. The list is non-exhaustive as the ARIADNE network is continuously growing (ARIADNE Foundation, n.d.).

Of course, combinations of the models above are possible. Writers like Osterwalder and Pigneur (2009) and Teece (2010) point to the importance of an explicit analysis of the combination of models, in relation to the internal and external possibilities, to avoid conflicts in the use of resources or market approaches.

However, if open is defined in a strict sense, meaning that no kind of payment takes place between the users and the suppliers of OER, the only sustainable business model is the one based on grants and subsidies; whereas, the marketing motive can be a reason for an organization to compensate for the costs of the OER-supply. This means that any organization offering OER should organize testimonials and other proof that the goals of the financers are met. 


\section{New Business Model of OER: A Community-Based Model}

J ust as is the case with different kinds of patents and copyrights (Chesbrough, 2006), there is no open market in which supply and demand for OER-products is coordinated. The role of an OER-organization within the OER-system could be to organize the marketplace. Instead of three interactions between the end-user, with the institutions and individual suppliers (for materials), and with the government to testify to the importance of OER for its learning process, the end-user has only one relation, with the OER organization which coordinates the incoming streams of money, materials, and testimonials and the outgoing streams, distributing the comments with respect to the supplied materials, the testimonials, and the publicity.

Traditional educational institutions "earn" their income by both educational subsidies and student fees. In contrast, the OER organization "earns" its income through

- hosting activities,

- quality controls,

- distributional activities.

An OER organization in the sense above could be a real organization, such as MIT or the Open University, or a web-based platform, such as Ariadne or Opener.

The overview above indicated that sustainability of OER would depend on the construction of a non-monetary exchange system: depending on non-monetary exchange rather than monetary trade. By combining the targets of the different stakeholders, organizing an exchange of products, the independent OER-organization could create a sustainable system. As stated by Truyen et al. (2011, p. 7), “(..) it becomes clear that OER can only function as part of a well thought-through network that embeds the course in the knowledge and human activity domain it pertains to". Truyen et al. (2011, Figure 1) does situate OER in the middle between several stakeholders (also see the slides from the presentation by Truyen, 2011 at the OER-HE stakeholder workshop at Leuven, 2011).

Here, we see the organization supplying OER (called OER-organization) as the center of a network, consisting of different stakeholders. This network will be called the OERsystem for short, and we assume that it consists of individuals and other organizations using and providing OER, as other institutions and organizations with different motives to participate in OER (governments, institutions, etc.).

Value networks will emerge when there are externalities (Eriksson, 2010). MarshallArrow-Romer indicates that firms will cooperate when there is differentiation and segmentation, leading to specialization (Eriksson, 2010, p. 14). The aim of cooperation is then cost reduction. Jacobs's externalities appear when there is a congestion of similar firms, leading to co-production and integration (Eriksson, 2010, p. 15). These 
kinds of externalities explain the appearance of Florida's creative cities and Silicon Valley. Verna Allee (as cited in Eriksson, 2010) sees the reason for cooperation in the realization of value through tangible relationships (formal, contracts) and intangible relationships (informal learning, knowledge sharing).

Of course, money should enter the system somewhere. The question is why organizations should cooperate within an OER-system. By restating the motives in terms of the products wanted and supplied, we can try to express the reasons for exchanges within this system. The financial relationships could then be minimized in volume if not in importance.

Based on the motives of the participants in the OER-process, as described above, we can distinguish several products supplied and demanded by the participants in the total OER-system (Table 2).

Table 2

Products Supplied and Demanded by the Participants in the OER-System

\begin{tabular}{lll}
\hline Products demanded & Participant & Products supplied \\
\hline $\begin{array}{l}\text { Testimonials } \\
\text { Efficiency (materials) }\end{array}$ & Government & Finances \\
Knowledge economy & & \\
(degrees and informal & & \\
learning) & & \\
\hline $\begin{array}{l}\text { Reputation } \\
\text { Altruistic motives }\end{array}$ & Individual supplier & Materials \\
Comments & & \\
\hline Materials & & \\
Comments & Institutional suppliers and & Efficiency (materials) \\
Reputation & users & Degrees \\
Knowledge about OER and & & \\
e-learning & & \\
\hline Materials: content and & Individual users & Testimonials \\
knowledge & & Comments \\
Degrees & & Informal learning \\
\hline & & Knowledge about OER and \\
& & -learning \\
& & Degutation and altruism \\
\hline & & \\
\hline
\end{tabular}


In our future research we will extend this model, providing an abstract business model to analyze existing business models of OER organizations, using value networks: the value of partnerships. We will tackle the question: If a sustainable business model is dependent on the way the partnerships are modeled, what will be the role of value networks in the sustainability?

By incorporating these topics and using research on actual behavior (as has been done in OERNED), the model above will be extended and improved. Using this model it should be possible to describe the organizational consequences of sustainability, using Osterwalder's Canvas (Osterwalder \& Pigneur, 2009).

Value networks are used to analyze different business perspectives, as of cloud computing (Leimeister et al., 2010; Ojala \& Tyrväinen, 2011), open source software (Morgan et al., 2010), open access (Rieger, 2011), and organizations in general (Vanhaverbeke \& Cloodt, 2006; Oksanen et al., 2010). The conclusions of this research can be used to develop a model for OER. This article concludes with the do's and don'ts resulting from these network analyses.

Morgan et al. (2010) describe the role of value networks in open source software (OSS), where OSS is seen as a community-based model, in which geographically dispersed programmers collaborate to produce software. Success is described to depend on

1. a high level of commitment,

2. the volume and frequency of knowledge exchange, and

3. the alignment of the goals of network participants.

From Rieger (2011) we can learn the importance of

1. a network of stakeholders, the integration in the academic community, and mandate/ governance system;

2. the systematic development of content;

3. the importance of stability versus innovation;

4. user-based strategies and feedback cycles, user central.

The organizational research starts from the customers' needs, which (according to Okasanen et al., 2010, p. 381) defines "the features and attributes of its production." In this case, a group of organizations will link together in a sense that "all the participants of the consortium benefit." The value network is seen as an extended enterprise (Okasanen et al., 2010, p. 384). However, in their view the reason for participating in a network and the success factors do not only differ over firms and sectors, but also, over the four stages of development, they differ in the dynamics of value networks. However, a "collective view on the dynamics" is important in all stages of the value network (Okasanen et al., 2010, p. 394). 
From the analysis of value constellations Vanhaverbeke and Cloodt (2006) found instances of inter-organizational networks linking firms with different assets and competencies together in response to or in anticipation of new market opportunities. However, depending on the sector in which the collaboration takes place, it also seems to be the case that almost identical firms find it easier than other firms to cooperate. Yet, creating and capturing value neither happens spontaneously nor is it the result of an adaptation process of firms to changes in the business environment. It requires a central firm that explores the potential to create value for customers in radically new ways and shapes the external environment accordingly through acquisitions, licensing agreements, non-equity alliances, joint ventures, contracting, and other types of relations that go beyond arm's-length relations.

Also important is the perception of a fair value distribution in a value constellation, because some actors are automatically better off in the new constellation compared to the old value creating system, but others might be worse off and have to be compensated to get/ stay committed to the value constellation.

In conclusion, there seem to be some common requirements for the success of networks in different constellations. Most studies stress the importance of alignment in the strategy/goals of participants, of fairness as the distribution over the supply chain can change, and - in some cases - leadership within the network.

The emergence of an OER-value network should take into account that the different participants should be "seduced" to participate. In this sense the OER-organization should take the lead, whereas towards other participants (other institutions or the government) taking the lead would be counter-productive. A conceptual model should be developed, based on the conclusions of the value network models in other sectors and industries, to analyze the existing OER-organizations before more definitive conclusions can be drawn. 


\section{References}

ARIADNE Foundation. (n.d.) Retrieved from http:// www.ariadne-eu.org/repositories

Afuah, A. (2004). Business models. A strategic management approach. Boston : McGraw-Hill.

Bitter-Rijpkema, M. E., \& De Langen, F. (2012). Positioning the OER business model of open education. EURODL, 07.03.2012. Retrieved from http:// www.eurodl.org/ ?article=483.

Business Model Generation. (2011, September 1). Business model canvas explained. Retrieved from http:// youtu.be/ QoAOzMTLP5s

Chesbrough, H. (2006). Open innovation models: How to thrive in the new innovation landscape. Boston Massachusetts : Harvard Business School Press.

Davos World Economic Forum (2011). Retrieved from http:// www.weforum.org/ videos/davos-annual-meeting-2010-highlights-0

Dholakia, U. W., King, R., \& Baraniuk (2006). What makes an open education program sustainable? The Case of Connexions. Retrieved from http:// www.oecd.org/ dataoecd/3/6/36781781.pdf

Downes, S. (2006). Models for sustainable open educational resources. National Research Council Canada.

Eriksson, A. (Ed.) (2010). The Matrix-Post Cluster Innovation Policy. VINNOVA, rapport 2010/ 10. Retrieved from www.vinnova.se/ upload/ .../vr-10-10.pdf

ETA. (2011). News release, Obama administration awards nearly $\$ 500$ million in first round of grants to community colleges for job training and workforce development. Retrieved from http:// www.dol.gov/opa/ media/press/ eta/ eta20111409.htm

Guthrie, K., Griffiths, R., \&Maron, N. (2008). Sustainability and revenue models for online academic resources (An Ithaka Report). Retrieved from http://sca.jiscinvolve.org/ 2008/ 06/ 03/ download-final-ithaka-report-onsustainability/

Hylén, J . (2009). Why individuals and institutions share and use OER. In S. D’Antoni \& C. Savage (Eds.), Open educational resources: Conversations in cyberspace (Chapter 8). UNESCO.

J anssen, B., \& Schuwer, R. (2012). Open educational resources and business models. In R. J acobi \&N. van der Woert (Eds.), Trend rapport open educational resources 
(pp. 62 - 65). Surf Special Interest Group Open Educational Resources (in Dutch ).

Koohang, A., \& Harman, K. (2007). Advancing sustainability of open educational resources. Issues in Informing Science and Information Technology, 4, 535544.

Kumar, M. S. V. (2009). Open educational resources in India's national development. Open Learning: The J ournal of Open and Distance Learning, 24(1), 77-84. Retrieved from http:// www.informaworld.com/smpp/title content=t713440064

Lane, A. (2008). Reflections on sustaining open educational resources: An institutional case study. eLearning Papers, 10, September. Retrieved from http:// www.elearningeuropa.info/ out/ ?doc_id=15736\&rsr_id=16677

Langen, F.H.T. de (2008). Business cases in an electronic environment: Lessons for eeducation? Working Papers on Management, GE 08-01, Open University, March.

Langen, F.H.T. de (2011). There is no business model for OER: A business model approach. Open Learning: The J ournal of Open and Distance Learning, 26(3).

Leismesiter, S. M. Böhm, C., Riedl, \& Krcmar, H. (2010). The business perspective of cloud computing: Actors, roles and value network. ECIS 2010 Proceedings, Paper 56. Retrieved from aisle.aisnet.org/ ecis2010/56

Marshall, S., \& C. Casserly (2006). The promise of open educational resources. Change: The Magazine of Higher Learning, 38(5), 8-17.

Morgan, L., J ., Feller, \& Finnegan, P. (2010). Open source as open innovation: Creating and capturing value in value networks. Proceedings of IFIP 8.2/Organisations and Society in Information Systems, Sprouts: Working Papers on Information Systems, 10(106). Retrieved from sprouts.aisnet.org/ 10-106

Mulder, F. (2011, November). Classical and digital openness in a fascinating blend: Global? Institutional? Keynote speech at the Eadtu Annual Conference, Eskisehir, Turkey.

Obama, B. (2011). State of the Union Address.

Ojala, A., \& Tyrväinen, P. (2011). Value networks in cloud computing. J ournal of Business Strategy, 326, 40-49.

Oksanen, P., Hallikas, J ., \& Sissonen, H. (2010). The evolution of value networks. Int. J . Networking and Virtual Organizations, 7(4), 381- 398. 
Osterwalder, A. (2004). The business model ontology: A proposition in a design science approach (Thesis). l'Ecole des Hautes Etudes Commerciales de l'Université de Lausanne. Retrieved from http://www.hec.unil.ch/aosterwa/PhD/Osterwalder_PhD_BM_Ontology.pdf

Osterwalder A., \& Pigneur, Y. (2009). Business model generation. Self-published.

Porter, M. E. (1985). Competitive advantage. New York. NY: Free Press.

Prahalad, C. K., \& Krishan, M. S. (2008). The new age of innovation. New York : McGraw-Hill.

Rieger, O. Y. (2011). Assessing the value of open access information systems: Making a case for community based sustainability models. J ournal of Library Administration, 51(5-6).

Stacey, P. (2012). The economics of open [Web log post]. Retrieved from http://edtechfrontier.com/

Teece, D. J . (2010). Business models, business strategy and innovation. Long Range Planning, 43, 172-194.

Truyen, F. (2011). The many good reasons for open educational resources [Slides]. Retrieved from http:/ / www.slideshare.net/ Ftruyen/good-reasonsforoer2

Truyen, F., Van Dorp, K., J anssen, B., Rivera, J ., Griset, R., \& Kuppens, A. (2011). Open educational resources in a multi-campus and virtual campus environment. In L. Gómez Chova, D. Martí Belenguer, \&A. López Martínez (Eds.), EDULEARN11 Proceedings CD (pp. 001248-001258). EduLearn. Barcelona, Spain: International Association of Technology, Education and Development (IATED).

Vanhaverbeke, W., \& Cloodt, M. (2006). Open innovation in value networks. In H.Chesbrough, W. Vanhaverbeke \&J.West (Eds.), Open innovation: Researching a new paradigm. Oxford University Press.

Watters, A. (2011). Appropriations bill may strip federal funding for open educational resources [Web log post]. Retrieved from http:// www.hackeducation.com/2011/ 10/ 05/ appropriations-bill-may-stripfederal-funding-for-open-educational-resources/

Wiley, D. (2012). RIP, OER? [Web log post]. Retrieved from http:// opencontent.org/ blog/archives/ 2177

Wit, B. de, \&Meyer, R. (2005). Strategy synthesis. London : Cengage Learning EMEA. 
Athabasca University $\mathbf{I}$

(c) 